\title{
Feeding plans with the use of glycerin for broilers
}

\author{
Edna Teles dos Santos', Leilane Rocha Barros Dourado ${ }^{*}$, Flávio Ferreira da Silva', Regina \\ Fialho de Sousa', Stélio Pinheiro Bezerra de Lima', Jefferson Costa de Siqueira²
}

\author{
'Federal University of Piaui, Bom Jesus, Brazil \\ ${ }^{2}$ Federal University of Maranhão, Chapadinha, Brazil \\ *Corresponding author, email: leilane@ufpi.edu.br
}

\begin{abstract}
This study aimed to evaluate the effects of feeding plans with or without addition of glycerin, in different ages, on performance, carcass yield, litter moisture and footpad lesions of broiler chickens. 540 male Cobb broilers were utilized, distributed in a completely randomized design with six treatments (treatments consisted of the inclusion or not of glycerin in diets at all periods or only at different stages: 1 to 7,8 to 21,22 to 33 and 34 to 42 days), in six replicates of 15 birds each. Diets were provided ad libitum. At 42 days, the average weight, weight gain, feed intake, feed conversion, carcass yield, litter moisture and footpad lesions were evaluated. There was no effect $(p>0.05)$ of dietary plans on the performance variables. The feeding plans did not influence $(p>0,05)$ the carcass and cuts parameters at 42 days. However, there was significant effect $(p<0.05$ ) of the dietary plans on litter moisture and plantar lesions. Effects were observed $(p>0,001)$ for the feeding plans, were the highest and the lowest incidence of lesions were present in the birds that consume diets with and without addition of glycerin, in the period from 1 to 42 days of age, respectively.
\end{abstract}

Keywords: Alternative Feeds, footpad lesions, glycerol, litter moisture, performance

\section{Introduction}

Broiler production depends essentially on the availability of ingredients whose prices are compatible with those paid per kilogram of poultry meat, since feeding is one of the fundamental factors in the production cost. Due to the high costs of the ingredients which compose broiler diets, producers have sought alternatives to minimize these expenditures.

The energy ingredients are the major components of poultry diets, with corn being their main representative. Today, the glycerin originated from biodiesel production has been introduced as an alternative energy source in poultry feeding. Because of its energy value, crude glycerin might most likely be able to partially replace the ingredients that are carbohydrate sources in the formulation of animal diets (Dozier et al., 2008).

Several research experiments have been performed in the last few years evaluating glycerin in poultry feeding. However, many data diverge in terms of energetic value, since there is a wide variation in the type of glycerin produced for animal feeding. According to Dozier et al. (2011), the main variations observed are related to the water, sodium, methanol, free fatty acids and glycerol contents, which consequently affect the energy use by the animal.

Several studies demonstrate that the 
maximum inclusion level is highly variable, depending on the chemical composition of the glycerin and the life stage in which the birds are (Dozier et al., 2008; Dozier et al., 2011 ; Guerra et al., 2011; Henz et al., 2014). There are some specific recommendations for the usage of glycerin in the four broiler rearing phases (Guerra et al., 2011) or in the entire period with accumulated effect (Silva et al., 2012), however, no studies evaluating the residual effect of glycerin inclusion alone, in distinct phases, on the final performance, have been found.

The present study was conducted aiming to evaluate performance, carcass yield, litter moisture content and footpad lesions in broilers subjected to different feeding plans with or without inclusion of glycerin in the diets, in different rearing phases.

\section{Material and Methods}

Location and Period - The experiment was performed in the Poultry and Slaughtering Section of Colégio Técnico de Bom Jesus, Piauí state, Brazil. The experimental period was from April 18 to May 31, 2012. Maximum and minimum temperatures and relative air humidity were daily recorded using hygrometers, placed at the height of the birds.

Facilities- Thirty-six $2 \mathrm{~m}^{2}$ experimental pens were used. Tubular baby-chick feed troughs were utilized from the first to the seventh days of rearing, being then replaced for adult-type tubular feeders, until the end of the experiment. The water drinkers utilized were of the automaticbell type. The litter was composed of rice straw (first use) with $5 \mathrm{~cm}$ thickness. The shed in which the pens were installed was of the conventional type, with $26 \mathrm{~m}$ of length by $8 \mathrm{~m}$ of width, ceramic tile roofing, concrete floor and masonry side walls with $40 \mathrm{~cm}$ in height, continued with wire mesh up to the roof height, provided with movable curtains to help regulate the ventilation and temperature inside the shed. 150W incandescent bulbs were utilized for heating until seven days of age and/or whenever necessary.

Birds and Experimental Design - The chicks were vaccinated, still in the hatchery, against Marek's disease, Gumboro, Newcastle disease and infectious bronchitis, and did not receive any vaccinations during the experimental periods. 540 male broilers of the Cobb strain were distributed in a completely randomized design, with six treatments and six replicates, totalizing 36 experimental units, with 15 birds each. Treatments were defined by the feeding plans with and without glycerin, in all phases or in different rearing phases, according to the scheme in Table 1.

Table 1. Treatments (feeding plans) with glycerin in the four phases of poultry rearing.

\begin{tabular}{|c|c|c|c|c|}
\hline \multirow{2}{*}{ Treatments } & \multicolumn{4}{|c|}{ Age (days) } \\
\hline & $1-7$ & $8-21$ & $22-34$ & $35-42$ \\
\hline $\mathrm{Tl}$ & Basal $^{1}$ & Basal $^{1}$ & Basal $^{1}$ & Basal $^{1}$ \\
\hline T2 & Glycerin² & Glycerin² & Glycerin² & Glycerin ${ }^{2}$ \\
\hline T3 & Glycerin $^{2}$ & Basal $^{1}$ & Basal' $^{1}$ & Basal $^{1}$ \\
\hline $\mathrm{T} 4$ & Basal' $^{1}$ & Glycerin² & Basal' $^{1}$ & Basal $^{1}$ \\
\hline T5 & Basal' $^{1}$ & Basal $^{1}$ & Glycerin² & Basal $^{1}$ \\
\hline T6 & Basal $^{1}$ & Basal $^{1}$ & Basal $^{1}$ & Glycerin² $^{2}$ \\
\hline
\end{tabular}

The birds were individually weighed and distributed into the experimental plots, so that the treatments presented an initial average weight of $39.7 \mathrm{~g}$. A continuous lighting program was adopted throughout the experimental period.

Experimental Diets - The diets were formulated based on corn and soybean meal, in order to meet the nutritional requirements of male broilers of regular performance, according to the recommendations of Rostagno et al. (2011). The glycerin levels in the experimental diets were $7 \%$ and $0 \%$ for the diets with and without glycerin, respectively. The composition of the glycerin utilized in the experimental diets is shown in Table 2 , and the proximate and calculated composition of each of the experimental diets is presented in Table 3. Birds received feed and water ad libitum in the entire experimental period. 
Table 2. Nutritional, physicochemical and energetic composition of glycerin utilized in the diets.

\begin{tabular}{|c|c|}
\hline Character & Result \\
\hline Sulfated ash ${ }^{1} \%$ & 7,20 \\
\hline Chlorine ${ }^{1} \%$ & 3,55 \\
\hline $\mathrm{NaCl}^{1} \%$ & 5,84 \\
\hline Residual methanol ' \% & 0,003 \\
\hline Sodium ${ }^{1} \%$ & 2,29 \\
\hline Monoglycerides ${ }^{1} \%$ & 1,30 \\
\hline Glycerol' \% & 80,95 \\
\hline Humidity \% & 10,60 \\
\hline Density at $20^{\circ} \mathrm{C}^{1} \mathrm{~g} / \mathrm{ml}$ & 1,26 \\
\hline Acidity $\%$ & 0,90 \\
\hline $\mathrm{pH}^{1}$ & 6,20 \\
\hline Gross energy kcal/kg & 3774 \\
\hline Metabolizable energy ${ }^{2} \mathrm{kcal} / \mathrm{kg}$ & 3585 \\
\hline
\end{tabular}

Table 3. Proximate composition and calculated nutrient levels of the basal and glycerin diets in the studied rearing phases of broilers.

\begin{tabular}{|c|c|c|c|c|c|c|c|c|}
\hline \multirow{3}{*}{ Ingredients } & \multicolumn{8}{|c|}{ Rearing Phases (days of age) } \\
\hline & \multicolumn{2}{|c|}{$1-7$} & \multicolumn{2}{|c|}{$8-21$} & \multicolumn{2}{|c|}{$22-33$} & \multicolumn{2}{|c|}{$34-42$} \\
\hline & Basal & Glyc. & Basal & Glyc. & Basal & Glyc & Basal & Glyc \\
\hline Corn & 55,14 & 46,70 & 62,12 & 53,51 & 64,49 & 56,03 & 68,53 & 60,07 \\
\hline Soybean meal $45 \%$ & 37,90 & 39,38 & 32,45 & 33,98 & 30,01 & 31,50 & 26,68 & 28,17 \\
\hline Soybean oil & 2,03 & 2,05 & 1,36 & 1,46 & 1,98 & 2,01 & 1,83 & 1,85 \\
\hline Glycerin ADM & 0,00 & 7,00 & 0,00 & 7,00 & 0,00 & 7,00 & 0,00 & 7,00 \\
\hline Common salt & 0,51 & 0,11 & 0,48 & 0,08 & 0,45 & 0,05 & 0,44 & 0,04 \\
\hline DL- methionine MHA 84 & 0,42 & 0,43 & 0,33 & 0,34 & 0,27 & 0,28 & 0,24 & 0,25 \\
\hline L-Lysine 79 & 0,28 & 0,25 & 0,24 & 0,21 & 0,19 & 0,16 & 0,19 & 0,16 \\
\hline Ammonium chloride & 0,00 & 0,36 & 0,00 & 0,36 & 0,00 & 0,36 & 0,00 & 0,36 \\
\hline Calcitic Limestone & 0,91 & 0,90 & 1,05 & 1,05 & 0,94 & 0,93 & 0,83 & 0,82 \\
\hline Inert & 0,50 & 0,50 & 0,10 & 0,10 & 0,00 & 0,00 & 0,00 & 0,00 \\
\hline Dicalcium phosphate & 1,91 & 1,92 & 1,50 & 1,50 & 1,24 & 1,25 & 1,02 & 1,03 \\
\hline Vitamin supplement - Nutron ${ }^{1}$ & 0,40 & 0,40 & 0,40 & 0,40 & 0,40 & 0,40 & 0,20 & 0,20 \\
\hline \multicolumn{9}{|c|}{ Nutritional composition and energy } \\
\hline Potassium (\%) & 0,85 & 0,85 & 0,77 & 0,77 & 0,76 & 0,76 & 0,68 & 0,68 \\
\hline Chlorine (\%) & 0,35 & 0,35 & 0,34 & 0,34 & 0,32 & 0,32 & 0,31 & 0,31 \\
\hline Linoleic acid (\%) & 2,48 & 2,35 & 2,21 & 2,11 & 2,56 & 2,43 & 2,53 & 2,40 \\
\hline EMA (kcal/kg) & 2920 & 2920 & 2980 & 2980 & 3050 & 3050 & 3100 & 3100 \\
\hline Crude protein (\%) & 22,0 & 22,0 & 20,0 & 20,0 & 19,0 & 19,0 & 17,80 & 17,80 \\
\hline Calcium (\%) & 0,92 & 0,92 & 0,86 & 0,86 & 0,75 & 0,75 & 0,65 & 0,65 \\
\hline Available phosphorus (\%) & 0,47 & 0,47 & 0,38 & 0,38 & 0,33 & 0,33 & 0,29 & 0,29 \\
\hline Dig. methionine (\%) & 0,64 & 0,64 & 0,54 & 0,55 & 0,49 & 0,49 & 0,45 & 0,45 \\
\hline Dig. Met + Cystine (\%) & 0,94 & 0,94 & 0,82 & 0,82 & 0,75 & 0,75 & 0,70 & 0,70 \\
\hline Dig. Iysine. (\%) & 1,30 & 1,30 & 1,14 & 1,14 & 1,04 & 1,04 & 0,96 & 0,96 \\
\hline Sodium (\%) & 0,22 & 0,22 & 0,21 & 0,21 & 0,20 & 0,20 & 0,19 & 0,19 \\
\hline
\end{tabular}

Glyc = glycerin. Provides / kg (pre-starter) diet: folic acid $-200.00 \mathrm{mg}$, biotin-10,00 mg; chloro-hydroxyquinoline $-7500,00 \mathrm{mg}: \mathrm{Zn}$ $-17.50 \mathrm{~g}$, vit. A - 1,680,000.00 IU, vit. B1 - $436.50 \mathrm{mg}$, vit. $2400.00 \mathrm{mcg} \mathrm{B12,} \mathrm{vit.} \mathrm{B2} \mathrm{-} 1200.00 \mathrm{mg}$, vit. B6 - $624 \mathrm{mg}$, vit. D3 - 400,000.00 IU, vit. And, 3500.00 IU, vit. K 3 to $360.00 \mathrm{mg}$, Niacin $-8399.00 \mathrm{mg}$; nicarbazin $-25.00 \mathrm{~g}$ : Pantothenic acid $-3120.00 \mathrm{mg}$; hill -78.10 g if-75, $00 \mathrm{mg} ; 11.25 \mathrm{~g} \mathrm{Fe}, \mathrm{Mn}-18,74 \mathrm{~g}$; Cu $-1997.00 \mathrm{mg}, \mathrm{I}-187.00 \mathrm{mg}$. (Initial): Folic acid - $199.00 \mathrm{mg}$, biotin-10, $00 \mathrm{mg}$; chlorohydroxyquinoline - 7500, 00mg: $\mathrm{Zn}-17.50 \mathrm{~g}$, vit. A - 1,680,000.00 IU, vit. B1 - $436.50 \mathrm{mg}$, vit. $2400.00 \mathrm{mcg}$ B12, vit. B2 - $1200.00 \mathrm{mg}$, vit. B6 - $624.00 \mathrm{mg}$, vit. D3 - 400,000.00 IU, vit. And, $3500.00 \mathrm{IU}$, vit. K 3 to $360.00 \mathrm{mg}$, Niacin - $8400.00 \mathrm{mg}$; monensin - 25,00g, pantothenic acid - $3119.00 \mathrm{mg}$; choline $-80.71 \mathrm{~g}$ if-75, $00 \mathrm{mg}$, iron $11.25 \mathrm{~g}$, Mn - 18, 74g, copper -1996.00 mg, id - $187.47 \mathrm{mg}$. (Growth): Folic acid - $162.50 \mathrm{mg}$; chloro-hydroxyquinoline $7500,00 \mathrm{mg}: \mathrm{Zn}-17.50 \mathrm{~g}$, vit. A - 1,400,062.50 IU, vit. B1 - $388.00 \mathrm{mg}$, vit. $2000.00 \mathrm{mcg}$ B12, vit. B2 - $1000.00 \mathrm{mg}$, vit. $520.00 \mathrm{mg} \mathrm{B6}$, vit. D3 - 360,012.00 IU, vit. And, $2500.00 \mathrm{IU}$, vit. K 3 to $300.00 \mathrm{mg}$, Niacin - $7000.00 \mathrm{mg}$; salinomycin -16.50 g: Pantothenic acid - $2600.00 \mathrm{mg}$; hill - $71.59 \mathrm{~g}$ if-75, 00mg; $11.25 \mathrm{~g} \mathrm{Fe}$, Mn - 18, 74g; Cu -1996.00 mg, I- 187.47 mg. (Final / slaughter): Folic acid - $162.50 \mathrm{mg}$, zinc oxide - $17.500 \mathrm{mg}$; If $-75 \mathrm{mg}$, vit. A - $1.400 .00 \mathrm{IU}$, vit. B1 - $388 \mathrm{mg}$, vit. B12 $2000 \mathrm{mc}$; vit. B2 - 1,000 mg, vit. B6 - 520 mg, vit. D3 - 1,600 IU, vit. And, 2,500 mg, vit. K 3-300 mg, Zn - 70 ppm; Niacin - 7.000 mg, Pantothenic Acid - $2.600 \mathrm{mg}$; choline - 71593.49 mg, 11.250 mg Fe, Mn - $18.750 \mathrm{mg}$; Cu -2.000 mg, I - $187.50 \mathrm{mg}$, antioxidant additive $25000 \mathrm{mg}$, $7.500 \mathrm{mg}$ halquinol, $16.500 \mathrm{mg}$ salinomycin. 
Evaluated traits - Feed intake (g/bird), weight gain, average weight (g/bird), feed conversion (g feed/g weight gain), carcass yield, litter moisture (\%) and footpad lesions ( $\mathrm{mm}$ ) were evaluated.

Performance - Feed intake was calculated as the difference between the total feed supplied and the orts, corrected for the mortality, which was daily recorded to correct feed intake according to Sakomura \& Rostagno (2016). Weight gain was calculated in relation to the final and initial weights of each treatment. Based on the feed intake and weight gain data, the feed conversion of the animals was calculated at the end of the 42 days of age.

Carcass Yield - At 42 days, all birds were individually weighed, and from each experimental unit were removed 3 (three) birds with the closest possible weight to the average weight of the parcel, for slaughter.

The slaughter was performed in a meat-packing plant after the birds underwent a six-hour feed-deprivation period, in the following sequence: post-fasting individual weighing, stunning, bleeding, scalding, plucking, evisceration, chilling (for better removal of the abdominal fat) in a cold room for two hours, weighing of the eviscerated carcass, performing of the cuts, and weighing of each cut for later analysis of carcass and cuts yield. The following variables were determined: eviscerated carcass yield (ECY), defined as the ratio between fasted weight and carcass weight (slaughtered bird without feathers, blood, feet, neck, viscera or abdominal fat); and yields of breast (BY), drumstick (DY), thigh (TY), wing (WY), abdominal fat $(F Y)$, liver (LY) and heart $(H Y)$, which were determined as the ratio between these cuts and the carcass weight. The abdominal fat was defined as the fat around the cloaca, bursa of Fabricius, gizzard, proventriculus and the adjacent abdominal muscles.

Litter Moisture - The litter moisture analyses were performed in the Animal Nutritional Laboratory of the Federal University of Piauí (UFPI) Campus Professora Cinobelina Elvas (CPCE).

At 42 days of age, an average of $400 \mathrm{~g}$ of litter sample per pen was collected in order to determine the moisture content. Samples were collected in various points of each pen, with great attention, so as to minimize the moisture loss during both collection and storage of the material. After the collection, the samples were identified and homogenized, and approximately $200 \mathrm{~g}$ were removed, weighed on plastic trays and dried in a forced-circulation oven at $55^{\circ} \mathrm{C}$ for 72 hours. These samples were later weighed to determine the moisture content.

Paw Lesions - The footpad lesion scores of each bird were evaluated; the lesions were determined as follows: at 42 days of age all birds from each experimental unit were evaluated in order to check the presence or absence of footpad lesions. When confirmed, they were measured with a digital pachymeter in both paws and classified as: absent, small $(\leq 0.75 \mathrm{~mm})$ and large $(>0.75 \mathrm{~mm}))$, as proposed by Bilgili et al. (2009).

Statistical Analyses - The performance, carcass yield and litter moisture data were subjected to variance analysis through the GLM (General Linear Models) procedure of the SAS ${ }^{\oplus}$ (2002) software. Means were compared by the Student Newman Keuls (SNK) test with $a=0.05$. Data concerning footpad lesions were analyzed by the Chi-squared test.

\section{Results and Discussion}

The mortality recorded throughout the trial was $0 \%, 0.19 \%, 1.11 \%$ and $0.93 \%$ for the pre-starter, starter, grower and final phases, respectively, with no influence of the evaluated treatments.

The average temperature and humidity values recorded during the experimental period are presented in Table 4.

According to each phase, the values showed that the birds were under thermal discomfort (Abreu \& Abreu, 2011) during the experimental periods, since the thermal comfort zone recommended for chicks in the first week of life is within $32^{\circ} \mathrm{C}$ and $35^{\circ} \mathrm{C}$, and $23^{\circ} \mathrm{C}$ and $26^{\circ} \mathrm{C}$ for animals in the fourth week of life, with relative humidity between 60 and $70 \%$.

The average variables of average body weight ( $A B W$ ), weight gain (WG), feed intake (FI) and feed conversion (FC) of the birds subjected to the different feeding plans with and without 
inclusion of glycerin, in either all or in distinct phases, are presented in Table 5. No effect $(p<0,05)$ was observed for any of the studied variables, related to the development of the birds subjected to the different feeding plans, with an without addition of glycerin, in either all or in distinct phases.

Table 4. Average temperatures and humidity in each phase.

\begin{tabular}{ccccccc}
\hline Periods & \multicolumn{2}{c}{ Indoor air $\left({ }^{\circ} \mathrm{C}\right)$} & \multicolumn{2}{c}{ Litter $\left({ }^{\circ} \mathrm{C}\right)$} & \multicolumn{2}{c}{ Relative humidity (\%) } \\
\cline { 2 - 6 } (Days) & $\mathrm{MAX}^{1}$ & $\mathrm{MIN}^{1}$ & $\mathrm{MAX}^{1}$ & $\mathrm{MIN}^{1}$ & $\mathrm{MAX}^{1}$ & $\mathrm{MIN}^{1}$ \\
\hline 1 a 7 & 38,3 & 24,3 & 35,9 & 24,4 & 81,4 & 37,9 \\
8 a 21 & 38,3 & 22,3 & 36,5 & 21,9 & 72,0 & 23,0 \\
22 a 33 & 36,7 & 22,9 & 36,0 & 23,4 & 81,9 & 30,6 \\
33 a 42 & 37,5 & 24,0 & 36,5 & 22,5 & 77,1 & 27,1 \\
\hline
\end{tabular}

Table 5. Average weight (AW), weight gain (WG), feed intake (FI) and feed conversion (FC) of broilers subjected to feeding plans with and without glycerin.

\begin{tabular}{|c|c|c|c|c|c|c|c|c|}
\hline \multicolumn{9}{|c|}{ 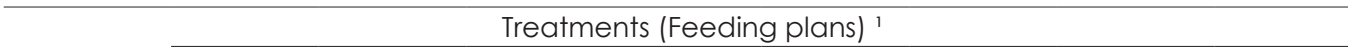 } \\
\hline Variables & 1 & 2 & 3 & 4 & 5 & 6 & \multirow[t]{2}{*}{ Probability ${ }^{2}$} & \multirow[t]{2}{*}{$\mathrm{CV}(\%)^{3}$} \\
\hline \multicolumn{7}{|c|}{1 to 42 days of age } & & \\
\hline AW (g) & 2304 & 2331 & 2309 & 2263 & 2291 & 2374 & 0,1497 & 2,74 \\
\hline WG (g) & 2265 & 2291 & 2269 & 2223 & 2251 & 2334 & 0,1499 & 2,77 \\
\hline $\mathrm{Fl}(\mathrm{g})$ & 3886 & 3970 & 3897 & 3885 & 3955 & 3988 & 0,5262 & 2,86 \\
\hline FC (g) & 1,716 & 1,732 & 1,717 & 1,747 & 1,757 & 1,710 & 0,2713 & 2,18 \\
\hline
\end{tabular}

Studies such as that by Waldroup (2007), utilizing addition levels of uo ti $10 \%$ with chicks at 16 days of age, as well as Batista (2010), testing levels of up to $16 \%$ crude or purified glycerol in quail diets from 15 to 35 days of age, and the work by Simon et al. (1996), utilizing diets with $10 \%$ glycerin in broiler feed, did not observe differences over weight gain, feed intake and feed conversion for a addition levels of up to $10 \%$ Silva et al. (2012), testing glycerin levels of up to $10 \%$ in broiler diets, obtained similar results for weight gain and average weight at 21 and 42 days of age.

The absence of effects over the development variables might have occurred due to the fact that the experimental diets supplied the nutritional demands of the birds, regardless of the addition or not of glycerin, so that both presented similar developments.

Similar performance responses were found by Cerrate et al. (2006), when they utilized up to $5 \%$ glycerin in diets for broilers at 14 days of age. Bernal et al. (1978), utilizing levels of up to $8,5 \%$ glycerin for broilers, obtained a worsening in feed conversion. Dozier et al. (2011) state that there is a wide variation in the chemical composition of the glycerin utilized in poultry feeding, consequently changing the metabolizable energy level of diets, what might explain the divergences observed among the studies conducted by several researchers.

Fernandes et al. (2010), utilizing levels of up to $8 \%$ glycerin in diets for broilers I the periods of 21 to 33 days of age, verified that this addition level did not compromise the feed intake, feed conversion, weight and viability, corroborating with the results of this present study, were no effect $(p>0,05)$ was found for feed intake and feed conversion (Table 5) for the adopted feeding plans.

For Silva et al. (2012), levels of up to $10 \%$ glycerin do not impair the feed conversion of broilers at 42 days of age, although levels above $5 \%$ in diets, for 7-day-old broilers, do increase their feed intake. The authors explained the high intake as a result of the glycerin properties providing a better palatability to the diet.

Guerra et al. (2011), working with different glycerin inclusion levels in diets for broilers, observed that levels above $4 \%$ interfered negatively with the feed conversion in the entire rearing period (one to 42 days), because as the inclusion of crude glycerin in the diet was increased, feed conversion worsened in relation 
to the control diet.

Table 6 presents the average litter moisture data of 42-day-old broilers according to the experimental treatments.

It was observed that the feeding plans in which the birds consumed diets with and without glycerin, throughout the experimental period and in distinct phases, did influence the litter moisture values $(\%)$ at 42 days $(P<0.05)$.

Table 6. Litter moisture (LM) of broiler chickens at 42 days subjected to feeding plans with and without glycerin.

\begin{tabular}{|c|c|c|c|c|c|c|c|}
\hline \multirow[b]{2}{*}{ Variable } & \multicolumn{6}{|c|}{ Treatments (Feeding plans)' } & \multirow[b]{2}{*}{ Probability $^{2} \mathrm{CV} \%^{3}$} \\
\hline & 1 & 2 & 3 & 4 & 5 & 6 & \\
\hline \multicolumn{8}{|c|}{ At 42 days of age } \\
\hline LM (\%) & $28,9 \mathrm{AB}$ & $32,9 \mathrm{~A}$ & $27,0 A B$ & $23,3 \mathrm{~B}$ & $28,9 \mathrm{AB}$ & $36,1 \mathrm{~A}$ & 0,011 \\
\hline
\end{tabular}

The highest litter moisture was observed in the treatments in which diets containing glycerin were supplied in all rearing phases, and/or only in the last phase (34 to 42 days), compared with those fed only in the period of 8 to 21 days. With regard to the other feeding plans without glycerin or with glycerin in the phases of 1 to 7,22 to 33 , and 34 to 42 days, no differences were found $(P>0.05)$. These results corroborate those of Cerrate et al. (2006), who observed that the litter of the pens in which birds were fed diets containing the highest level of glycerin (10\%) was moister than the litter where birds were fed the control diet, or the diet with $5 \%$ glycerin. Similar responses were found by Guerra et al. (2011), who utilized crude glycerin levels of up to $10 \%$ in diets, and observed an increase in litter moisture at 21 and 42 days of age. Similar results for litter moisture have also been found in quails (Pasquetti et al., 2014) and layer hens (Lammers et al., 2008) fed diets containing crude glycerin levels above $7.5 \%$.

Cerrate et al. (2006) and Lammers et al. (2008) explain that the high litter moisture might have been caused by the increase in the sodium and/or potassium levels of the diet, since in these studies the sodium content of glycerin was not corrected in the diets, possibly exceeding the nutritional recommendations of sodium for these animals. Oliveira et al. (2010) claim that the increase in litter moisture might occur due to the electrolytic balance of the diet, wherein as the electrolytic balance was elevated, a greater litter moisture value was obtained. In the present study, the sodium levels were corrected, and all diets had the same level; thus, the increased moisture litter in this study was not resulting from the increase in the sodium levels.

The high hygroscopicity of glycerin (Quijada-Garrido et al., 2007) might elevate the moisture of broiler litters, since once glycerol is in excess in the organism of an animal, it can be excreted by the kidneys through urine and by blood filtration (Lin et al.,1977). Thus, part of the water that would be reabsorbed links to the glycerol, and both (glycerol and water) are filtered by the kidneys and eliminated via urine. This would probably increase the water intake of the animals, because the water which would be reutilized in the organism ends up being eliminated together with the glycerol, and this might explain the obtained results, since the supplied diets contained the same sodium content and similar electrolytic balance. This assumption is reinforced by the study of Gianfelici et al. (2011), in which it is reported that broilers were able to metabolize diets containing pure glycerol up to the level of $7.5 \%$, and above that, there was an increase in the level of free glycerol in the blood, excretion and water intake.

It was observed that the birds fed diets containing glycerin in the period from 1 to 42 days of age (Table 7) showed a higher incidence of small and large lesions $(P<0.001)$. The lowest incidence of lesions was observed in the birds that did not consume diets containing glycerin in the period from 1 to 42 days of age, just as those that received glycerin from 1 to 7 days of age only.

Silva (2010), utilizing diets with glycerin addition levels of up $10 \%$, verified that as the levels increased, the bird presented more severe lesions, in comparison with the animals of the control diet. The increase in the size of the lesions 
Table 7. Footpad lesion scores in 42-day-old broilers subjected to feeding plans with and without glycerin

\begin{tabular}{ccccccc}
\hline \multirow{2}{*}{ Treatments $^{1}$} & \multicolumn{2}{c}{ Absent } & \multicolumn{2}{c}{ Small $(\leq 7,5 \mathrm{~mm})$} & \multicolumn{2}{c}{ Large $(>7,5 \mathrm{~mm})$} \\
\cline { 2 - 7 } & AFR $^{2}$ & RFR $^{3}$ & AFR $^{2}$ & RFR $^{3}$ & AFR $^{2}$ & RFR $^{3}$ \\
\hline 1 & 76 & $(45,0)^{* * *}$ & 53 & $(31,4)$ & 40 & $(23,7)$ \\
2 & 34 & $(19,9)$ & 72 & $(42,1)^{* * *}$ & 65 & $(38,0)^{* * *}$ \\
3 & 68 & $(38,0)^{* * *}$ & 72 & $(40,2)^{* * *}$ & 39 & $(21,8)$ \\
4 & 60 & $(35,3)$ & 53 & $(31,2)$ & 57 & $(33,5)$ \\
5 & 42 & $(23,6)$ & 80 & $(44,9)^{* * *}$ & 56 & $(31,5)$ \\
6 & 52 & $(30,2)$ & 62 & $(36,0)$ & 58 & $(33,7)$ \\
\hline
\end{tabular}

$11=$ Diets without inclusion of glycerin ( 1 to 42 days); 2 = Diets with the inclusion of glycerin ( 1 to 42 days); $3=$ Diets with inclusion of glycerin only from 1 to 7 days; $4=$ Diets with inclusion of glycerin only from 8 to 21 days; $5=$ Diets with inclusion of glycerin only from 22
to 33 days and $6=$ Diets with inclusion of glycerin only from 34 to 42 days. ${ }^{2} A F R$ : Absolute frequency and ${ }^{3}$ RFR: Relative Frequency.

to 33 days and $6=$ Diets with inclusion of glycerin
$*$ Significant through Chi-square test $(p<0.001)$.

has a direct relation with the quality of the litter, and this evaluation is relevant, since that Brazil has increased the export of paws in the last decades. In this study, it was observed that some ingredients supplied to broilers might also contribute to increasing footpad lesions, given that when two nutritional plans - without and with inclusion of glycerin (7\%) were adopted in the period from 1 to 42 days of age - lower and higher incidences of footpad lesions were obtained in broilers, respectively.
The results for the yields of carcass, breast, drumstick, thigh, wings, abdominal fat, liver and heart at 42 days of age, in birds fed different feeding plans, are presented in Table 8.

No effect $(P>0.05)$ was observed on the parameters of carcass and cuts, evaluated according to the studied feeding plans in the period from 1 to 42 days of age.

It was observed that all feeding plans might be utilized for male broilers without

Table 8. Yield of eviscerated carcass (YEC), of Chest (YC), Thighs (YT), Leg quarters (YLQ), Wings (YW), Abdominal fat (YAF), Liver (YL) and heart (YH) of broilers at 42 days age, subjected to feeding plans with and without glycerin.

\begin{tabular}{|c|c|c|c|c|c|c|c|c|}
\hline \multirow{2}{*}{ Yield (\%) } & \multicolumn{6}{|c|}{ Treatments $^{1}$} & \multirow{2}{*}{ Probability $^{2}$} & \multirow{2}{*}{$C V(\%)$} \\
\hline & 1 & 2 & 3 & 4 & 5 & 6 & & \\
\hline YEC & 75,9 & 75,8 & 75,2 & 75,2 & 74,5 & 75,6 & 0,1382 & 1,24 \\
\hline YC & 32,9 & 33,7 & 33,6 & 33,9 & 33,7 & 33,4 & 0,6794 & 3,23 \\
\hline YT & 14,3 & 14,2 & 14,0 & 13,9 & 14,2 & 14,4 & 0,6873 & 4,02 \\
\hline YLQ & 16,0 & 15,7 & 15,7 & 14,4 & 15,7 & 15,4 & 0,8328 & 4,99 \\
\hline YW & 10,8 & 10,7 & 11,1 & 10,9 & 10,7 & 10,7 & 0,3133 & 2,92 \\
\hline YAF & 2,34 & 2,38 & 2,14 & 2,41 & 2,22 & 2,14 & 0,4066 & 12,77 \\
\hline YL & 2,01 & 2,21 & 2,20 & 2,15 & 2,18 & 2,45 & 0,0879 & 10,88 \\
\hline $\mathrm{YH}$ & 0,64 & 0,68 & 0,63 & 0,68 & 0,65 & 0,60 & 0,2252 & 10,10 \\
\hline
\end{tabular}

affecting the carcass and commercial cuts yields. These results are similar to those found by Gianfelici et al. (2011), who utilized levels of up to $10 \%$ glycerin in diets for 38-day-old broilers.

Silva et al. (2012) found no significant effect for the carcass traits (carcass yield, breast yield, thigh yield, back yield, wing yield, and abdominal fat) with the usage of different levels of glycerin (0\%, 2.5\%, 5.0\%, $7.5 \%$ and $10 \%$ ) in broiler diets. Guerra et al. (2011) also did not observe significant effect in broilers fed different levels of glycerin in two feeding plans (22 to 42 and 1 to 42 days old), except for abdominal fat, in which the glycerin level in the diet reduced the abdominal fat weight.

Similar results for carcass yield were found by Cerrate et al. (2006), utilizing up to $5 \%$ glycerin in diets for 42-day-old broilers. In another experiment, Cerrate et al. (2006), testing up to 5\% glycerol for birds of the same category, observed an increase in the percentage of breast and a decrease in the percentage of wings. Based on these results, the utilization of feeding plans with addition of glycerin in the diet of male broilers, 
in the period of 1 to 42 days of age might be utilized, since in levels of up to $7 \%$, they do not affect the broiler carcass characteristics.

\section{Conclusions}

Feeding plans with inclusion of $7 \%$ glycerin can be utilized as an energy source in diets in the entire rearing period ( 1 to 42 days of age) or in any of the four phases (1 to 7, 8 to 21 , 22 to 33 and 34 to 42 days) without affecting the performance or carcass yields of broilers.

Inclusion of $7 \%$ glycerin in diets for broilers of 1 to 42 days of age, or only from 34 to 42 days of age only, promotes an increase in their litter moisture.

The incidence of footpad lesions in broilers increases when they are fed diets containing $7 \%$ of inclusion of glycerin in the period from 1 to 42 days of age.

\section{Acknowledgments}

The the Federal University of Piaui (UFPI) for the support; to the Colégio Técnico de Bom Jesus- PI for the facilities; and to the GENPAS group for the collaboration. To ADM for glycerin donation.

\section{References}

Abreu, V.M.N., Abreu, P.G. 2011. Os desafios da ambiência sobre os sistemas de aves no Brasil. Revista Brasileira de Zootecnia 40: 1-14.

Bilgili, S.F., Alley, M.A., Hess, J.B., Blake, J.P., Macklin, K.S., Sibley, J.L. 2009. Influence of bedding material on footpad dermatitis in broiler chickens. Journal of Applied Poultry Research 18: 583-589.

Cerrate, S., Yan, F., Wang, Z., Coto, C., Sacakli, P., Waldroup, P.W. 2006. Evaluation of glycerine from biodiesel production as a feed ingredient for broilers. International Journal of Poultry Science 5: 1001-1007.

Dozier, W.A., Kerr, B.J., Branton, S.L. 2011. Apparent metabolizable energy of crude glycerin originating from different sources in broiler chickens. Poultry Science 90: 2528-2534.

Dozier, W.A., Kerr, B.J., Corzo, A., Kidd, M.T., Weber, T.E., Bregendahl, K. 2008. Apparent metabolizable energy of glycerin for broiler chickens. Poultry Science 87: 317-322.

Gianfelici, M.F., Ribeiro, A.M.L., Penz Jr, A.M., Kessler, A.M., Vieira, M.M., Machinsky, T. 2011. Determination of apparent metabolizable energy of crude glycerin in broilers chickens.
Brazilian Journal of Poultry Science 13: 255-258.

Guerra, R.L.H., Murakami, A.E., Garcia, A.F.Q.M., Urgnani, F.J., Moreira, I., Picoli, K.P. 2011 . Glicerina bruta mista na alimentação de frangos de corte (1 a 42 dias). Revista Brasileira Saúde e Produção Animal 12: 1038-1050.

Henz, J.R., Nunes, R.V., Eyng, C., Pozza, P.C., Frank, R., Schone, R.A., Oliveira, T.M.M. 2014. Effect of dietary glycerin supplementation in the starter diet on broiler performance. Czech Journal of Animal Science 59:557-563.

Lammers, P.J., Kerr, B.J., Honeyman M.S., Stalder, K., Dozier, W.A., Weber, T.E., Kidd, M.T., Bregendahl, K.2008. Nitrogen-corrected apparent metabolizable energy value of crude glycerol for laying hens. Poultry Science 87: 104107.

Lin, M.H., Romsos, D.R., Leveille, G.A. 1977. Effect of glycerol on lipogenic enzyme activities and on fatty acid synthesis in the rat and chicken. The Journal of nutrition 106: 1668-1677.

Oliveira, M.C., Arantes, U.M., Stringhini, J.H. 2010. Efeito do balanço eletrolítico da ração sobre parâmetros ósseos e da cama de frango. Revista Biotemas 23: 201-207.

Pasquetti, T.J., Furlan, A.C., Martins, E.N., Ton, A.P.S., Batista, E., Pozza, P.C., Grieser, D.O., Zancanela, V. 2014.Glicerinabruta para codornas de corte, de um a 14 e de 15 a 35 dias de idade. Arquivo Brasileiro de Medicina Veterinária e Zootecnia 66: 1547-1556.

Quijada-Garrido, I., Iglesias-gonzález,V., MazónArechederra, J.M. 2007. The role played by the interactions of small molecules with chitosan and their transition temperatures. Glass-forming liquids: 1,2,3-Propanetriol (glycerol). Carbohydrate Polymers 68: 173-186.

Rostagno, H.S., Albino, L.F.T., Donzele, J.L., Gomes, P.C., Oliveira, R.F., Lopes, D.C., Ferreira, A.S., Barreto, S.L.T., Euclides, R.F. 2011 .Tabelasbrasileiras para aves e suínos: composição de alimentos e exigências nutricionais. $3^{a}$ ed. UFV, Viçosa, Brasil. $252 \mathrm{p}$.

Sakomura, N.K., Rostagno, H.S. 2016. Métodos de pesquisa em nutrição de monogástricos. Funep, Jaboticabal, Brasil. 262p.

SAS Institute. SAS Users guide: Statistics. Version 8. Carry, NC, 2002.

Silva, C.L.S., Menten, J.F.M., Traldi, A.B., Pereira, R., Zavarize, K.C., Santarosa, J.2012. Glycerine derived from biodiesel production as a feedstuff for broiler diets. Brazilian Journal of Poultry Science 14: 159-232. 